\title{
A VÁLLALATI BELSŐ TÉNYEZŐKRE ALAPOZOTT KLASSZIKUS ÉS MODERN STRATÉGIAELMÉLETEK EGYSÉGES KERETBE FOGLALÁSA
}

A szerző ebben a tanulmányban a vállalati belső tényezőkkel foglalkozó stratégiaelméletek klasszikus és modern irányzatainak bemutatását tűzte ki célul. Az elméletek láthatóan nemcsak a megkezdett gondolatok továbbépítésével, hanem egymás vitatásával is igyekeznek teret nyerni, ezért releváns kísérletet tenni a legfontosabb következtetések egységes keretbe foglalására.

Az ágazatok többségére hiperverseny jellemző, és ez markáns kihívás elé állítja a versenyelőnyök tartósságát. Még az olyan időtállónak tartott előnyök, mint a kedvező versenypiaci pozícióból, sajátos piaci struktúrákból fakadó (pl. monopolizált piacokon elért) erőfölény gyakorlati jelentősége is csökkenő. Mindemellett az is ismeretes, hogy az erőforrásokban leginkább bővelkedő, legjobban informált vállalatokban is hoznak rossz vagy szuboptimálisnak tekinthető döntéseket, kialakulnak belső korlátok, teljesítményt meghatározó szűk keresztmetszetek.

Ezekre a kihívásokra a modern stratégiaimenedzsment-elméletek, így a dinamikus képességalapú elméletek, a felfedezésorientált stratégia irányzata, valamint a viselkedési stratégia teóriái egyaránt igyekeznek válaszokat adni. Az tapasztalható, hogy az átmeneti előnyök egymást permanensen követő sorozatára törekvő vállalat számára az erőforrások és képességek mintázata és a penrose-i értelemben vett sokfélesége válik lényegessé, a Barney-féle VRIO-kritériumokkal szemben. Az erőforrás- és képességkonfiguráció megfelelő hasznosításával összefüggésben más belső tényezők, így a döntés és végrehajtás összhangját biztosító szervezeti struktúra, valamint a felső vezető(k) személyéhez köthető tényezők jelentősége is egyre nagyobb. ${ }^{1}$

Kulcsszavak: stratégiaelméletek, vállalati belső tényezők, szervezeti struktúra, felső vezetők

A stratégiaimenedzsment-elméletek döntő többsége a(z időben) fenntartható versenyelőny megszerzésének és megtartásának módjával foglalkozik (Deutsch - Mészáros - Szabó, 2017). A diszciplína 60 éves fejlődéstörténetének mérföldköveit jelentő szakirodalmakban azonban nincs minden esetben egyetértés arról, hogy a vállalat teljesítményét milyen forrásból származó előnyök alakítják, valamint azok hogyan és milyen mértékben fejtik ki hatásukat.

Az 1970-es évek olajválságai, a gazdasági környezet változékonysága és kiszámíthatatlansága kapcsán a vállalati tervezés jelentősége megnövekedett (Grant, 2016). Ennek következtében a döntően pénzügyi nézőpontú tervezési gyakorlatot a más szempontokat is figyelembe vevő preskriptív tervezési iskolák váltották fel. Az 1980as években egyes elemzésekben (pl. BCG, 1970) azt vizsgálták, hogy a profit iparági szereplők közötti eloszlását milyen tényezők befolyásolják (pl. piaci részesedés hatása, költségvizsgálatok), majd Porter (1980) korai, iparági tényezőket - versenyerőket - hangsúlyozó tanulmánya is megjelent. Eszerint, ha a vállalat képes gazdasági erőfölényt vagy természetes, jogi, piaci korlátok mentén sajátos piaci struktúrát kiépíteni, akkor az adott ágazatban chamberlaini járadék elérésére aspirálhat (mely a Bain-féle (1949) fogyasztói többlet lefölözésén alapuló monopolista járadék).
Az 1980-as évek végére általánosan elfogadottá vált a PIMS (Profit Impact of Market Strategy) elemzés (Buzzell - Gale, 1987), melynek szemlélete szerint egy vállalat nyereségességét a vállalati belső tényezők és az iparági tényezők együttesen alakítják.

Az 1990-es évektől kezdve többen (pl. Schmalensee, 1985; Montgomery - Wernerfelt, 1988; Rumelt, 1991; Roquebert et al., 1996; McGahan - Porter, 1997; Hawawini et al., 2003; Misangyi et al., 2006) is rávilágítottak arra, hogy a profitabilitást inkább magyarázzák a belső, mint az iparági tényezők. A felsorolt szerzők empirikus kutatásaikban egy üzleti egység vagy vállalat profitabilitásának (általában ROA-ban mérve) mindössze a 4-20\%-át tudták megmagyarázni külső/iparági tényezőkkel. A vállalati belső tényezők szerepének vizsgálatai ekkor kerültek elötérbe.

\section{A belső tényezőkön alapuló klasszikus versenyelőny-elméletek és azok kritikái}

Az 1990-es években a stratégiaalkotás középpontjába a versenyelöny elérésére alkalmas belső vállalati tényezők kerültek: az erőforrások és képességek, valamint azok rendszerei. A megközelítés kiterjedt és folyamatosan bővülő nemzetközi szakirodalmi bázissal rendelkezik (pl. Penrose, 1959; Rumelt, 1984; Teece, 1984, 1997; Werner-

${ }^{i}$ Köszönetnyilvánítás

„A kutatást az Emberi Erőforrások Minisztériumának Felsőoktatási Intézményi Kiválósági Programja finanszírozta, a Pécsi Tudományegyetem 4. tématerületi „A hazai vállalatok szerepének növelése a nemzet újraiparosításában” programja keretében (szerződés száma: 20765-3/2018/FEKUTSTRAT).” 
felt, 1984; Barney, 1991, 1995, 2001; Peteraf, 1993; Collis - Montgomery, 1995; Rugman - Verbeke, 2002; Grant, 1991, 2016; Nason - Wiklund, 2018). Az erőforrás-alapú elméletek alapfelvetése szerint ricardói járadék származik olyan erőforrásokból, melyek költsége alacsonyabb az általuk realizált haszonnál. A járadék megszünik akkor, amikor az erőforrás elavul, elértéktelenedik, vagy más vállalatok lemásolják. Versenyelőnyt birtokol az a vállalat, amely a versenytársainál nagyobb gazdasági értéket állít elő (Barney - Hesterly, 2014).

A folytatás fogalmi megalapozása érdekében szükséges definitív eszközökkel különbséget tenni (1) erőforrások, (2) szervezeti képességek és (3) alapvető kompetenciák között:

(1) Az erőforrások a vállalat tulajdonában lévő termelési eszközök, az értékteremtő folyamatok (tágan értelmezett) inputjai. Grant (2016) három csoportjukat különbözteti meg: megfogható erőforrások (pl. fizikai erőforrások, pénzügyi erőforrások), nem megfogható erőforrások (pl. technológia, hírnév, márka, szervezeti kultúra), humán erőforrások (pl. egyéni/alkalmazotti tudás, készségek, motiváció).

(2) Az erőforrások legtöbbször nem termelékenyek és nem alakítják a szervezeti teljesítményt önmagukban. Egy adott feladat végrehajtása érdekében a vállalat általában több erőforrást müködtet együtt, azokat szervezeti folyamataiba ágyazva transzformálja és/vagy kombinálja. A vállalat egy szervezeti képessége azt jelenti, hogy az erőforrásokat egy kívánt végeredmény elérése érdekében hasznosítani tudja (Helfat - Lieberman, 2002). Hamel és Prahalad (1992), valamint a későbbi források (pl. Grant, 2016) is felvetik azt, hogy a szervezeti képesség és a kompetencia fogalmai - tartalmukat tekintve - használhatóak egymás szinonimáiként.

(3) Az alapvető kompetenciák olyan kompetenciák, amelyek a vevőértékhez és/vagy az érték előállításának hatékonyságához kiemelkedő mértékben járulnak hozzá, és/vagy alapjául szolgálnak új piacokra történő belépéshez (Hamel - Prahalad, 1992), így a vállalat stratégiájára is és teljesítményére is alapvető hatást gyakorolnak (Prahalad - Hamel, 1990). Tekintettel arra, hogy az alapvető kompetenciák általában összetettek és rendszerszerűek, ráadásul esetenként több, önmagában is bonyolult erőforrásból és képességből épülnek fel (Gelei - Schubert 2006), ezért felszínre kerül a kompetenciakonfiguráció vizsgálatának jelentősége. A Miller-féle konfigurációs elmélet (Miller, 1986; Miller - Whitney, 1999) is az alapvető kompetenciák szerkezetének, benne az erőforrások és képességek mintázatának, kombinációinak másolhatatlanságot eredményező sajátosságát emeli ki. Ez a tevékenységek folytatásának egyedi módja alapján biztosít versenyelőnyt.

Az erőforrás-alapú megközelítés müvelői (pl. Wernerfelt, 1984, 1995; Conner, 1991; Peteraf, 1993; Barney, 2001; Grant, 2016) szerint az erőforrások és képességek potenciálisan alkalmasak arra, hogy a vállalat számára versenyelőny forrásául szolgáljanak. Ennek vizsgálatára hozták létre a VRIO üzleti elemzési keretrendszert. A VRIO-elemzés előfeltételezése az, hogy az erőforrások heterogének, immobilak, és az információk sem tökéletesek. A VRIO dimenziói az alábbiakban foglalhatóak össze:

1) $\mathrm{Az}$ erőforrás értékes-e ( $\mathrm{V}=$ valuable)? Értékes egy erőforrás akkor, ha alkalmazásával a vállalat képes lehetőségeket kihasználni vagy veszélyeket elhárítani.

2) Az erőforrás ritka-e $(\mathrm{R}=$ rare $)$ ? Az erőforrást a versenytársak ne birtokolják, illetve ne férjenek hozzá.

3) Az erőforrás nem másolható, nem utánozható ( $\mathrm{I}=$ inimitable)? Ez a feltétel biztosítja az erőforrás által elérhető versenyelőny tartósságát.

4) $\mathrm{Az}$ erőforrás a szervezetben beágyazott-e $(\mathrm{O}=$ organizational fit $)$ ? Ez a feltétel egyrészt az erőforrás birtoklásának jelentőségén túl arra hívja fel a figyelmet, hogy az erőforrást hasznosítani is tudni kell, másrészt annak szervezeten átívelő jellegéből fakadó másolhatatlanságát is hangsúlyozza.

Egy erőforrás és képesség akkor szolgálhat tartós versenyelőny alapjául, ha valamennyi feltételt kimeríti.

Ebben a felfogásban a stratégia fókuszában átfogóan a versenyelőny alapjául szolgáló, kimagasló teljesítményü erőforrások és képességek állnak, amelyekkel a vállalat a porteri (1980) megkülönböztetésre vagy költségvezetésre vonatkozóan kedvezőbb, eredményesebb pozíciót tud versenytársaihoz képest kiépíteni és fenntartani. Az üzleti stratégia fókuszában pedig azok a funkcionális területek állnak, amelyhez a versenyelőnyt biztosító erőforrások és képességek kötődnek. Az azonban kérdéses, hogy a versenytársakét meghaladó gazdasági érték előállítása szempontjából a tartós versenyelönyre vagy az átmeneti versenyelőnyök egymást permanensen követő sorozatára történő törekvés kedvezőbb-e. Ez utóbbi kockázatot, de a müködést fundamentálisan befolyásoló változásokkal szemben nagyobb stratégiai szintű rugalmasságot és a versenytársak előtt nehezebb kiszámíthatóságot eredményez.

Az alapvető kompetenciák sajátosságait figyelembe kell venni a stratégia formálása során. Kimondottan káros lehet - emeli ki Porter (2008) - az, ha a vállalat túlságosan ambiciózus növekedési célokra szűkíti stratégiai céljainak spektrumát. Amikor az értékteremtésben részt vevő beszállítók, kapacitások és új munkaerő száma gyorsan nő, akkor az alapvető kompetenciák kiváló teljesítménye erodálódhat. Ezzel összefüggésben többen (pl. Rosenzweig et al., 2003; Deutsch et al., 2013) a belső integritás mellett az integráció külső, ellátási lánc mentén történő fokozásának jelentőségére hívják fel a figyelmet. Az alapvető kompetenciák szempontjából hasonlóan kétséges kimenetele lehet annak, ha a termék és/vagy a termelési folyamat minőségében és/vagy komplexitásában következnek be változások (pl. Rideg, 2014). Porter (2008) az alapvető 
kompetenciák erózióját egyértelmüen a rossz stratégiai döntésekkel hozza összefüggésbe. Az erőforrás-alapú megközelítés logikáját ezért szükséges összehangolni a vállalati stratégia kialakításának egyes lépéseivel, ahogyan azt Grant $(2008,11$. o.) is javasolja. Ebben a logikában az alapvető kompetenciák a vállalat rendelkezésére álló ,stratégiai eszközök".

Nason és Wiklund (2018) világítanak rá arra, hogy az erőforrás-alapú megközelítés VRIO-elemzése hatékonyság-központú, és ebben a tekintetben - a szakirodalmi bázisban általában elhanyagolt - különbség fedezhető fel a Penrose (1959) által kidolgozott eredeti alapvetésekhez, valamint a korai szakirodalomhoz képest. Azokban ugyanis az erőforrások sokféleségére helyezték a hangsúlyt, mely a potenciálisan nyújtható termékek/szolgáltatások széles köre miatt biztosít stratégiai rugalmasságot, alkalmazkodóképességet. Nason és Wiklund (2018) empirikus kutatásaikban a vállalatok növekedésének mértékét igyekeztek az erőforrásokkal összefüggésbe hozni az erőforrás-alapú megközelítés mindkét irányzata mentén, és a penrose-i gyökerek alapján felépített módszerrel nyertek jobb magyarázatot.

A versenyelőnyök klasszikus elméleteinek korlátaira már számos szerző felhívta a figyelmet (pl. Priem - Butler, 2001; D’Aveni et al., 2010; McGrath, 2013b). Indoklásuk szerint a D'Aveni-féle (1994) hiperverseny, a müködési környezet változékonysága, bizonytalansága és nehéz tervezhetősége az ágazatok túlnyomó többségének jellemzőjévé vált, ezért mind a versenyelőnyök erodálódásának, mind az új lehetőségek keletkezésének üteme felgyorsult. Ezzel párhuzamosan a kiépített versenyelönyök is egyre kevésbé bizonyulnak tartósnak (McGrath, 2013a, 2013b). A versenyelőny-elméletek túlzottan statikus felfogására Madhok és Marques (2014) is felhívják a figyelmet.

Többen vitatják a versenyelőny-elméletek azon állítását is, miszerint az ágazaton belüli teljesítménykülönbségek csak a versenyelőnyökkel lennének magyarázhatók, hiszen a szakirodalomban bemutatott válogatott példák leginkább extrém pozitívak, tehát az adott ágazat egésze szempontjából a következtetések nem univerzálisak (pl. Denrell, 2004; Powell, 2003; Powell - Lloyd, 2005).

Az erőforrás-alapú megközelítés VRIO-elemzése kapcsán Powell és Arregle (2007) arra is figyelmeztetnek, hogy VRIO alapú módszertanok tévútra vihetik a döntéshozót. Indoklásuk szerint csak néhány nagyteljesítményü erőforrásnak van tényleges teljesítményformáló hatása, azoknak, amelyeket a vállalat sikerrel tud izolálni és „elrejteni” tevékenységeinek komplex, gyakran szervezeteket átívelő rendszereiben, a másolni kívánó versenytársak elöl.

\section{A belső tényezőkkel összefüggő korlátok, szűk keresztmetszetek, versenyhátrányok elméletei}

Miközben a stratégiai menedzsment szakirodalmában a stratégiaalkotás fókuszába a versenyelöny elérésére alkalmas vállalaton belüli tényezők kerültek, úgy jelentek meg azok a teóriák, mely a belső korlátok, versenyhátrányok, szűk keresztmetszetek feloldását hangsúlyozták. Goldratt az 1970-es évek végén vállalati felkérésre dolgoz- ta ki, majd 1980-ban publikálta az optimalizált termelési ütemterv/technológia elnevezésű (Optimized Production Timetable/Technology, röviden OPT) megoldását (Goldratt, 1980), mely kezdetben egy integrált termeléskészletezési rendszer volt.

Az OPT mindig az aktuális szük keresztmetszetre fókuszál, mely szűk keresztmetszet-definíció szerint olyan erőforrás, amelynek kapacitása egyenlő a piaci igénnyel vagy alacsonyabb annál, tehát meghatározza a teljes termelő vagy szolgáltató rendszer kapacitását, kibocsátó képességét (Goldratt - Cox 2014). (A kibocsátás ebben a logikában nem a megtermelt, hanem az értékesített termékeket jelenti.)

Az OPT-ot a tudomány nyelvén elöször Fry és szerzőtársai (1992) írták le, ezzel bevezették az akadémiai gondolkodás hétköznapjaiba. Az alkalmazás felszínre hozta azt, hogy minden rendszerben vannak a kibocsátást meghatározó szük keresztmetszetek, melyek feloldásával az output látványosan emelkedik. Ha a korlátok feloldása sikeres, akkor új szűk keresztmetszet keletkezik, ami a folyamatfejlesztés következő fókusza lesz. Ezzel a logikával a vállalat a kibocsátását - potenciálisan - fel tudja fejleszteni termelési lehetőségeinek maximumához.

Az OPT állomáshatékonyságot értékel, melyet össze kell hangolni azzal, hogy a munkahelyek többségében egyéni teljesítményértékelés zajlik. Ha egy nem szűk keresztmetszeti művelet túlműködik, vagy azt fejlesztik, akkor az csupán a raktárállomány növekedését okozza és nem a szervezet egészének teljesítménynövekedését. Goldratt számos, ipari vezetőknek tartott találkozáson igyekezett erre a veszélyre felhívni a figyelmet, sikertelenül. Válaszul Cox-szal közösen megírták „A cél, a folyamatos tökéletesítés módszere" címü könyvet, melynek célja nem a menedzseri szemlélet megváltoztatása, hanem az OPT-ot felhasználó munkatársak képzése volt. Ez a mü tekinthetö a korlátok elméletéhez (Theory of Constraints, röviden TOC) illeszkedő operatív müködés alapvető szakirodalmának (Goldratt - Cox 1984).

A TOC megreformálta a vállalati hatékonyságról való gondolkodást és a hatékony irányítás módszertanának egyik alapjává vált. Meghatározták továbbá a szervezet bármely funkciójánál, bármely müveleténél megtalálható szúk keresztmetszetek feloldásának lépéseit, így a TOC iránytű a vezetők számára a rendelkezésre álló fejlesztési források allokálásához is. A korlátok feloldására irányuló öt összpontosító lépés az alábbi:

1. szűk keresztmetszet azonosítása,

2. szük keresztmetszet megszüntetéséhez szükséges beavatkozás lehetséges módjainak számbavétele, megtervezése, az alternatíva kiválasztása,

3. a feltételek, erőforrások biztosítása,

4. szűk keresztmetszet megszüntetésére irányuló beavatkozás végrehajtása,

5. ha a szük keresztmetszet nem szünt meg, akkor viszsza kell lépni az első lépéshez. Ha a beavatkozás hatására új szűk keresztmetszet jött létre, akkor vissza kell lépni az első lépéshez (Goldratt - Cox, 1984 [2014]). 
Összességében a TOC gyakorlatának fókuszában a kritikus erőforrások felhasználásának hatékonysága, az erőforrás-pazarlás, a szűk keresztmetszetek feloldása és a kibocsátásmaximalizálás állnak. A pozitív vállalati példák hatására a TOC elméletei problémamegoldási megközelítésként lettek népszerüek és váltak a tudományos fóáram részévé (pl. Balderstone - Mabin, 1998; Watson et al., 2007; Şimşit et al., 2014). A TOC más gyakorlati alkalmazások (pl. a veszteségforrások megszüntetését középpontba helyező lean vállalatszervezési és -irányítási rendszerek, az átfutási és átállási idő fókuszú rugalmas termelési rendszerek, a kibocsátásingadozás és a selejtarány csökkentésére koncentráló hat szigma módszer (pl. Stamatis, 2004)) fejlődését is megalapozta vagy katalizálta.

A versenyelöny elméleteknek a TOC nem mond ellen, hanem alkalmasan egészíti ki azt az alacsony teljesítményü, korlátot jelentő belső tényezők fejlesztését hangsúlyozó nézőponttal. A versenyhátrányok elméletét és gyakorlatát vizsgáló más teoretikusok azonban a versenyelőny-elméletek több következtetését is vitatják.

Powell (2003) szerint az empirikus kutatásokban alkalmazott modellek gyakran „,túlmagyarázzák” a vállalati teljesítményt. A versenyelőnnyel rendelkező, profitabilis vállalatok esetei között is szép számmal találhatunk olyanokat, amelyeket látványos kudarcok rendítettek meg: lehetőségeket szalasztottak el, nem tudtak lemásolni másolható erőforrásokat, képtelenek voltak megoldani megoldható problémákat, belebuktak ambiciózus stratégiáik végrehajtásába. Gyakorlati tapasztalataik kapcsán kiemelik azt, hogy a legerősebb pozíciójú, erőforrásokban bővelkedő, legjobban informált vállalatok forráselosztása sem közelíti meg a globális optimumot (Powell - Arregle, 2007).

A szerzők szerint ennek oka nem a korlátozott racionalitásban, az okozati bizonytalanságban, a piaci vagy más kognitív korlátokban keresendő, hanem abban a felismerésben, hogy a gyakorlatban a tartós versenyelönyöket birtokoló vállalatok teljesítménye ugyanolyan heterogén, mint az azokkal nem rendelkező szereplőké. Ezt támasztják alá Denrell (2004) szimulációs kísérletei is, amelyek a teljesítmény hosszú távú iparági eloszlásának előre jelezhetetlen heterogenitását azonos és véletlen induló erőforráskészlet esetén ugyanúgy kimutatták. Az empirikus tapasztalatok szerint a teljesítmény iparági eloszlását számos vállalatspecifikus ok, diszfunkció, korlát, versenyhátrány (valamint ezek kombinációi) is befolyásolhatják (1. táblázat).
1. táblázat A teljesítményt formáló vállalati szintű diszfunkciók a szakirodalomban

\begin{tabular}{|l|l|}
\hline Szakirodalmi forrás & $\begin{array}{l}\text { A vizsgált diszfunkció } \\
\text { rövid leírása }\end{array}$ \\
\hline Ghemawat (1991) & $\begin{array}{l}\text { Cselekvési és mulasztási } \\
\text { hibák. }\end{array}$ \\
\hline Pfeffer és Sutton (2000) & $\begin{array}{l}\text { A tudás és a cselekvés } \\
\text { különbözősége. }\end{array}$ \\
\hline Lowenstein (2000) & $\begin{array}{l}\text { Hibák a hosszú távú } \\
\text { tökegazdálkodási } \\
\text { modellek gyakorlatában. }\end{array}$ \\
\hline $\begin{array}{l}\text { Allen (2001), } \\
\text { Aest és DeCastro (2001), }\end{array}$ & $\begin{array}{l}\text { Jövedelemtermelö } \\
\text { képességet romboló } \\
\text { eröforrások. }\end{array}$ \\
\hline Finkelstein (2003) & $\begin{array}{l}\text { A sikertelen döntéshozók } \\
\text { jellemzői. }\end{array}$ \\
\hline Powell (2004) & $\begin{array}{l}\text { A stratégia } \\
\text { végrehajtásának } \\
\text { diszfunkciói. }\end{array}$ \\
\hline March (2006) & $\begin{array}{l}\text { Adaptivitási hibák, } \\
\text { a komplex döntési } \\
\text { szituációk feltérképezésének } \\
\text { diszfunkciói. }\end{array}$ \\
\hline Jacobides (2006) & $\begin{array}{l}\text { Hibák a képességek } \\
\text { szerkezetében. }\end{array}$ \\
\hline
\end{tabular}

Forrás: saját szerkesztés

Ezek az elméletek - átfogóan összefoglalva - a belső korlátok, szük keresztmetszetek, versenyhátrányok jelentőségét, a kockázatos és bizonytalan döntési szituációk tervezhetőségét, a döntések és a végrehajtás sajátosságait, a döntéshozó egyéni képességeinek fontosságát és a véletlen szerepét emelik ki a teljesítmény alakulásában, ezzel az alapvető kompetenciák jelentőségének súlyát kérdőjelezik meg és a müködést befolyásoló tényezők klasszikus külső-belső tényező fókuszú vizsgálatának megfelelőségét is kihívás elé állítják.

A felsorolt és röviden bemutatott gondolkodók munkái alapozták meg a modern stratégiai menedzsmentben a „viselkedési stratégia” (behavioral strategy) kifejlődését, melynek fókuszában a stratégiai cselekvő (egyén) természetének, kognitív képességeinek és magatartásának, valamint a stratégiai tervezés, döntés, végrehajtás és értékelés folyamatai során felszínre kerülő objektív-üzleti 
és szubjektív-személyes érdekek szerepének vizsgálatai állnak (Powell et al., 2011; Das, 2014). Az új elméletek teoretikusai tehát láthatóan a korábbi eredményeket úgy vitatják, hogy azok inkább erőforrás/technika fókuszú közelítésmódját kiegészítik a szubjektív döntési/magatartási tényezőkkel.

\section{A vállalati belső tényezőkre alapozott elméletek egységes keretbe foglalása}

A stratégiai menedzsment modern gondolkodói közül kétség kívül Rita Gunther McGrath az egyik legmeghatározóbb. Azt állítja (McGrath, 2013a, 2013b), hogy a vállalatvezetők tartós versenyelőnyök elérésére törekednek, miközben ez napjaink turbulens gazdasági környezetében majdnem lehetetlen. Ehelyett a vállalatoknak újabb és újabb stratégiai kezdeményezésekkel kiépített átmeneti előnyök portfóliójára van szüksége, amelynek elemei legalább olyan gyorsan létrehozhatók, mint amilyen gyorsan elhagyhatók. Ezzel McGrath lefektette az átmeneti elönyök elméletének alapjait.

Amennyiben elfogadjuk McGrath állításait, úgy a klasszikus külső (versenypiaci pozíción) és belső tényezőkön (erőforrás- és képességbirtokláson) alapuló megközelítés helyett a hangsúly a stratégiai szintü rugalmasságon és a cselekvésen lesz, tehát azon, ahogyan a vállalat képes mások előtt a lehetőségeket kihasználni és a külső forrásból származó hatásokra, változásokra adaptívan reagálni. Ennek alapjaként ugyanúgy az erőforrások és képességek szolgálnak, de nem azok tulajdonlása/kisajátítása, hanem hasznosítása válik lényegessé. A kedvező versenypiaci pozícióból származó versenyelőny relevanciája nem vethető el, de elérése leginkább csak a nagyvállalatok számára lehetséges és esetükben is csupán ritkán tartós.

McGrath (2013a, 2013b) azt is kiemeli, hogy az átmeneti előnyök portfóliójának megfelelő menedzseléséhez számos stratégiai döntés meghozatalára van szükség, ezért az átmeneti előnyök elméletéhez illeszkedő gyakorlatban a stratégiai szintű cselekvők személyéhez köthető tényezők, a stratégiaalkotás és a döntéshozatal jelentősége nagyobb, mint korábban. Ajánlásai között hangsúlyosan jelennek meg a vállalkozói/kísérletezői kedvet, az innovációt, a szervezeti tanulást és fejlődést, a problémamegoldási képességet, valamint a kapcsolat- és hálózatépítést ösztönző intézkedések.

A folytatásban célszerü a klasszikus és modern stratégiaelméletek legfontosabb megállapításait egy egységes szempontrendszerű táblázatban összefoglalni (2. táblázat), ezzel átlátható a koncepciók fókusza, evolúciója, valamint belátható a modern versenystratégia gyakorlatához megfogalmazott javaslatok relevanciája.

A tartós versenyelönyök helyett tehát az kerül előtérbe, hogy hogyan képes a vállalat - a döntései és (kompetenciáit vagy azok kombinációit hasznosító) akciói által - a piaci lehetőségeket gyorsan megragadni és átmeneti versenyelőnyök egymást permanensen követő sorozatát biztosítani a maga számára. Ez a felfogás minden vállalat számára hasznosítható szempontokat nyújt a stratégia formálásához. Releváns kisebb méretű vállalatoknak is, mert ugyan elismeri, de nem hangsúlyozza a kedvező versenypiaci pozíció jelentőségét, és tartósnak sem tekinti azt.

Természetesen a modern stratégiaelmélet is nagymértékben épít a korábbi gondolkodók munkásságára: az alapvető építőkövek más - már klasszikusnak tekinthető - szerzők müveiből levezethetők akkor, ha felidézzük Penrose (1959) véleményét az erőforrások sokféleségéből származó előnyökről, valamint Hayes és Pisano (1994) felfogását a vállalatról, mint a képességek halmazáról. Az elmélet ajánlásai összecsengnek továbbá a képességalapú verseny (Teece et al., 1997) felvetéseivel, de elutasítja a külső és belső tényezők integrálása során kialakuló útfüggőség szükségszerüségét, helyette a dinamikus képességekre (Eisenhardt - Martin, 2000) és azok hasznosítására (Madhok - Marques, 2014) koncentrálnak.

A modern stratégiaelmélet sikeres gyakorlatához eröteljes vállalkozói orientáció (Lumpkin - Dess, 1996),

2. táblázat A vállalati belső tényezőkre alapozott stratégiaelméletek egységes szempontrendszerű összefoglalása

\begin{tabular}{|c|c|c|c|}
\hline & \multicolumn{2}{|c|}{ Klasszikus stratégiaelméletek } & \multirow{2}{*}{ Modern stratégiafelfogás } \\
\hline & Versenyelőny-elméletek & Versenyhátrány-elméletek & \\
\hline Cél & $\begin{array}{l}\text { Elsősorban tartós, másodsorban } \\
\text { átmeneti versenyelőnyök elérése. }\end{array}$ & $\begin{array}{l}\text { Versenyhátrányok elkerülése, } \\
\text { kiküszöbölése. }\end{array}$ & $\begin{array}{c}\text { Átmeneti versenyelőnyök egymást } \\
\text { követő sorozata. }\end{array}$ \\
\hline Kérdése & $\begin{array}{l}\text { Mely tényezők eredményeznek } \\
\text { versenyelőnyt? }\end{array}$ & $\begin{array}{l}\text { Mely tényezők okoznak } \\
\text { versenyhátrányt? }\end{array}$ & $\begin{array}{c}\text { Hogyan lesz és } \\
\text { marad versenyképes a vállalat? }\end{array}$ \\
\hline $\begin{array}{l}\text { Külső orientáció fókuszában } \\
\text { elsôsorban }\end{array}$ & $\begin{array}{c}\text { Kedvezö versenypiaci pozíció } \\
\text { az ágazatban. }\end{array}$ & $\begin{array}{l}\text { Intézményrendszer szerepe, } \\
\text { kedvezőtlen szabályozás, } \\
\text { kockázatok. }\end{array}$ & $\begin{array}{c}\text { Lehetőségek gyors azonosítása } \\
\text { az aréná(k)ban (mely a vevőpiaci } \\
\text { szegmens, az ajánlat jellemzőinek } \\
\text { és az ajánlat teljesítésének a } \\
\text { hármasa). }\end{array}$ \\
\hline $\begin{array}{l}\text { Belső orientáció fókuszában } \\
\text { elsôsorban }\end{array}$ & $\begin{array}{l}\text { VRIO-feltételeket kimerítő } \\
\text { erooforrások és képességek } \\
\text { birtoklása, kisajátítása és } \\
\text { fejlesztése. }\end{array}$ & $\begin{array}{l}\text { Korlátok, szük keresztmetszetek, } \\
\text { diszharmónia } \\
\text { a képességstruktúrában, tervezési, } \\
\text { döntési, végrehajtási hibák, } \\
\text { döntéshozó és cselekvők személye. }\end{array}$ & $\begin{array}{l}\text { Rugalmasság, adaptivitás, } \\
\text { döntéshozatal, képességek és } \\
\text { képességkombinációk } \\
\text { hasznosítása. }\end{array}$ \\
\hline Ahol felszínre kerül & $\begin{array}{l}\text { Tényezőpiac, termékpiac. } \\
\text { Versenyintenzitás csökken. }\end{array}$ & $\begin{array}{l}\text { Vállalati szint és stratégiai } \\
\text { cselekvők. }\end{array}$ & Értékteremtés folyamata. \\
\hline Érvényesség & $\begin{array}{l}\text { Elsősorban nagyvállalatok, } \\
\text { valamint monopolizált piacok. }\end{array}$ & Minden vállalat. & Minden vállalat. \\
\hline
\end{tabular}


értékajánlati nóvum, rugalmas struktúrák és hatásos vállalatkormányzás szükségesek (Teece, 2010; Zott Amit, 2010). Ezek támogatják a gyors döntéshozatalt, a szervezeti rugalmasságot és fejlődést, a döntések és az azok alapján foganatosított akciók összhangját, az eltérő feladatokat végző, eltérő erőforrásokat kezelő szervezeti egységek müködése közötti koordinációt, a hatékony végrehajtást, a gyors válaszadásnak, valamint az erőforrások gyors és összpontosított mozgósításának szervezeti képességeit. A vállalaton belül mindez a vezetésen és a képességmintázaton múlik, és az értékteremtés folyamatában kerül felszínre, ezért az elmélet versenyfelfogása összességében tekinthető az üzleti modellek/konfigurációk versenyének is.

A sikeres képességmintázatok azonosításával már a korai teoretikusok is foglalkoztak akkor, amikor azt kutatták, hogy az ágazati versenytársakhoz képest értelmezett hasonlóságok és különbözőségek a vállalat számára előnyöket vagy hátrányokat eredményeznek-e.

A kutatók egy része szerint (pl. Hawley, 1968; Henderson, 1981; Hannan et al., 1990; Porter, 1991; Barney, 1991; Baum - Mezias, 1992) a vállalati teljesítményre a különbözőségek fejtenek ki pozitív hatást, hiszen a megkülönböztetés és a fókuszált megkülönböztetés által a verseny csökken. A „kék óceán” érzékletes példájával él Mauborgne és Kim (2005), akik szerint a differenciáláson és innováción alapuló értékteremtéssel kvázi verseny nélküli szegletekben lehet (és érdemes) pozíciót építeni és tevékenykedni.

Más kutatók szerint az ágazaton belüli konformitás gyakorol pozitív hatást a teljesítményre ( $\mathrm{pl}$. Meyer - Rowan, 1977; Pfeffer - Salancik, 1978; DiMaggio - Powell, 1983; Hybels, 1995; Suchman, 1995). A felfogás alapja az, hogy a radikális eltérések a müködésben az iparági versenytársakhoz képest, valamint az értékajánlatban a vevőpiaci szegmentum elvárásaihoz képest, túlságosan kockázatosak. Az illeszkedés mértékét Deephouse (1999) a vállalatok ,legitimitásának fokának” nevezi.

Tehát az ágazaton belül a vállalatok közötti hasonlóság vagy különbözőség vezet sikerhez? A két felfogás között a Deephouse-féle (1999) stratégiai egyensúly elmélete hivatott összhangot teremteni, eszerint a vállalatoknak a magas fokú legitimitásra és a versenystratégia megkülönböztető jellegére egyaránt hangsúlyt kell helyezniük.

A kérdéskör frissebb szakirodalmában (pl. Deutsch et al., 2013) nem vetik el a legitimitás szükségességét, de előnyösnek azt az üzleti modellt tartják, mely vagy az adott iparágban általánosan alkalmazott üzleti modell alapján épül fel, de növelve annak hatékonyságát, vagy pedig az adott ágazatban még példa nélküli új üzleti modellt alakít ki. Ahogyan az Üzletimodell-építés címü üzleti bestseller szerzői, Osterwalder és Pigneur $(2010,43$. o.) is fogalmaznak: a sikeres üzleti modellek markánsan költség- vagy értékorientáltak.

Összefoglalva a leírtakat, a vállalat pénzügyi teljesítményét elsősorban a belső tényezők, a müködési rutinokba ágyazott erőforrások és a képességek mintázata alapján a vállalat döntéshozói formálják. A külső tényezők, a véletlen és a külső döntéshozók szerepe sem elvitatható, mégis kiemelendő, hogy a külső forrásból származó hatásokhoz, valamint az azok nyomán létrejövő lehetőségekhez és veszélyekhez történő alkalmazkodás is az adott vállalat döntéshozóin múlik.

\section{Összefoglalás}

A tanulmány a stratégiaimenedzsment-szakirodalom vállalati belső tényezőkkel foglalkozó elméleteinek öszszefoglalására, egységes keretbe foglalására, valamint a megnövekedett jelentőségű szervezeti jellemzők kiemelésére hivatott. A modern stratégia központi kérdése a tartós versenyelőnyöket biztosító erőforrások és képességek birtoklása, kisajátítása és fejlesztése helyett az, hogy hogyan képes a vállalat döntéseit és kompetenciáit - vagy azok kombinációit - hasznosító akciói által a piaci lehetőségeket gyorsan megragadni és átmeneti előnyök egymást permanensen követő sorozatát biztosítani maga számára. Mindez - a klasszikus versenyelőny-elméletek egy jelentős részével ellentétben - a kisebb méretű vállalatok számára is alkalmas nézőpontokat nyújt a stratégia formálásához, mert ugyan elismeri, de nem hangsúlyozza a kedvező versenypiaci pozíció (pl. monopolhelyzet) jelentőségét, és tartósnak sem tekinti azt.

A modern stratégia sikeres gyakorlata az értékteremtés folyamatában a vállalat vezetésén - a döntéshozó(ko)n -, a döntés és végrehajtás összhangját támogató szervezeti struktúrán, valamint az erőforrások és képességek mintázatán és szerkezetén múlik. Ezek a megnövekedett jelentőségű belső tényezők a stratégiai menedzsment klasszikus szakirodalmában (Penrose, 1959; Hayes - Pisano, 1994; Teece et al., 1997; Eisenhardt - Martin, 2000; Madhok Marques, 2014) ugyan már jól ismertek, de előremutató a megállapításokat az üzleti modellek/konfigurációk versenyével, valamint a legfrissebb, felfedezésorientált stratégiaelmélettel (McGrath, 2013a, 2013b) foglalkozó szakirodalmak eredményeivel összefüggésbe hozni.

\section{Felhasznált irodalom}

Allen, D. (2001): Hard currency. Financial Management, (January), p. 13.

Arend, R. J. (2004): The Definition of Strategic Liabilities, and their Impact on Firm Performance. Journal of Management Studies, 41(6), p. 1003-1027.

Bain, J. S. (1949): A note on pricing in monopoly and oligopoly. The American Economic Review, 39(2), p. 448-464.

Balderstone, S. J. - Mabin, V. J. (1998): A Review of Goldratt's Theory of Constraints (TOC)-lessons from the international literature. In: Annual Conference of the Operational Research Society of New Zealand. Auckland, ORSNZ.

Barney, J. (1991): Firm resources and sustained competitive advantage. Journal of Management, 17(1), p. 99-120.

Barney, J. B. (1995): Looking inside for competitive advantage. Academy of Management Executive, 9(4), p. 49-61.

Barney, J. B. (2001): Resource-based theories of competitive advantage: A ten-year retrospective on the resource-based view. Journal of Management, 27(6), p. 643-650.

Barney, J. B. - Hesterly, W. S. (2014): Strategic Management and Competitive Advantage: Concepts and Cases. 5th ed. Cambridge: Pearson Publishing 
Baum, J. A. - Mezias, S. J. (1992): Localized competition and organizational failure in the Manhattan hotel industry, 1898-1990. Administrative Science Quarterly, 37(4), p. 580-604.

Boston Consulting Group (1970): Perspectives on Experience. Boston: The Boston Consulting Group, 109 p.

Buzzell, R. D. - Gale, B. T. (1987): The PIMS Principles linking strategy to performance. New York: Free Press

Collis D. J. - Montgomery C. A. (1995): Competing on Resources: Strategy in the 1990s, Harvard Business Review, 73(4), p. 118-128.

Conner, K. R. (1991): A Historical Comparison of ResourceBased Theory and Five Schools of Thought Within Industrial Organization Economics: Do We Have a New Theory of the Firm? Journal of Management, 17(1), p. 121-154.

Das, T. K. (ed.) (2014): Behavioral Strategy: Emerging Perspectives (Research in Behavioral Strategy). Charlotte: Information Age Publishing, $260 \mathrm{p}$.

D'Aveni, R. A. (1994): Hypercompetition. New York: Free Press, $448 \mathrm{p}$.

D'Aveni, R. A. - Dagnino, G. B. - Smith, K. G. (2010): The age of temporary advantage. Strategic Management Journal, 31(13), p. 1371-1385.

Deephouse, D. L. (1999): To be different, or to be the same? It's a question (and theory) of strategic balance. Strategic Management Journal, 20(2), p. 147-166.

Denrell, J. (2004): Random walks and sustained competitive advantage. Management Science, 50(7), p. 922-934.

Deutsch, N. - Dravavolgyi, T. - Rideg, A. (2013): Note on the development of sustainable supply chain strategy. Chemical Engineering Transactions, 35, p. 655-660.

Deutsch N. - Mészáros T. - Szabó L. (2017): A stratégiai paradigmák fejlődésének holisztikus megközelítése. In: Veresné Somosi M. - Lipták K. (szerk.): „Mérleg és Kihívások" X. Nemzetközi Tudományos Konferencia: konferenciakiadvány. Miskolc-Lillafüred: ME-GTK, p. 130142.

DiMaggio, P. J. - Powell, W. W. (1983): The iron cage revisited-Institutional isomorphism and collective rationality in organizational fields. American Sociological Association, 48(2), p. 147-160.

Eisenhardt, K. M. - Martin, J. A. (2000): Dynamic capabilities: what are they? Strategic Management Journal, 21(1011), p. 1105-1121.

Finkelstein, S. (2003): Seven habits of spectacularly unsuccessful people. Business Strategy Review, 14(4), p. 39-50.

Fry, T. D. - Cox III, J. F. - Blackstone Jr., J. H. (1992): An analysis and discussion of the optimized production technology software and its use. Production and Operations Management, 1(2), p. 229-242.

Gelei A. - Schubert A. (2006): Kompetencia alapú versenyképesség egy vezető FMCG vállalat példáján. 72. sz. mühelytanulmány. Budapest: Budapesti Corvinus Egyetem, $27 \mathrm{p}$.

Ghemawat, P. (1991): Commitment: the dynamic of strategy. New York: Free Press, 178 p.

Goldratt, E. M. (1980): Optimized production timetables: a revolutionary program for industry. In: 23rd Annual International Conference of the American Production and
Inventory Control Society. Falls Church VA, APICS.

Goldratt, E. M. - Cox, J. (1984) [2014]: The Goal: A Process of Ongoing Inprovement. Croton-on-Hudson NY: North River Press, $362 \mathrm{p}$.

Grant, R. M. (1991): Toward the resource-based theory of competitive advantage: Implications for strategy formulation. California Management Review Spring, 33(3), p. 114-135.

Grant, R. M. (2008): Tudás és stratégia. Budapest: Alinea Kiadó, $328 \mathrm{p}$.

Grant, R. M. (2016): Contemporary Strategy Analysis. 9th ed. Chichester: John Wiley \& Sons, 776 p.

Hamel, G. - Prahalad, C. K. (1992): Capabilities-based competition (letters to the HBR). Harvard Business Review, 70(3), p. 164-165.

Hannan, M. T. - Ranger-Moore, J. - Banaszak-Holl, J. (1990): Competition and the evolution of organizational size distributions. In: Singh, J. V. (ed.): Organizational evolution: new directions. Newbury Park, CAL: Sage Publications, p. 246-268.

Hawawini, G. - Subramanian, V. - Verdin, P. (2003): Is Performance Driven by Industry or Firm-Specific Factors? A New Look at the Evidence. Strategic Management Journal, 24(1), p. 1-16.

Hawley, A. H. (ed.) (1968): Roderick D. McKenzie on Human Ecology: Selected Writings. Chicago: University of Chicago Press, $308 \mathrm{p}$.

Hayes, R. H. - Pisano, G. P. (1994): Beyond world class: the new manufacturing strategy. Harvard Business Review, 72(10), p. 77-86.

Helfat, C. E. - Lieberman, M. B. (2002): The birth of capabilities: market entry and the importance of pre-history. Industrial and Corporate Change, 11(4), p. 725-760.

Henderson, B. D. (1981): The concept of strategy. [online] Boston: The Boston Consulting Group. https://www.bcgperspectives.com/content/Classics/strategy_concept_of_ strategy/ (megtekintve: 2015.08.16.)

Hybels, R. C. (1995): On legitimacy, legitimation, and organizations: A critical review and integrative theoretical model. In: Moore, D. P. (ed.): Academy of Management Best Papers Proceedings, p. 241-245.

Jacobides, M. G. (2006): The architecture and design of organizational capabilities. Industrial and Corporate Change, 15(1), p. 151-171.

Lowenstein, $R$. (2000): When genius failed: the rise and fall of Long-Term Capital Management. New York: Random House, $288 \mathrm{p}$.

Lumpkin, G. T. - Dess, G. G. (1996): Clarifying the entrepreneurial orientation construct and linking it to performance. Academy of Management Review, 21(1), p. 135-172.

Madhok, A. - Marques, R. (2014): Towards an action-based perspective on firm competitiveness. BRQ Business Research Quarterly, 17(2), p. 77-81.

March, J. G. (2006): Rationality, foolishness, and adaptive intelligence. Strategic Management Journal, 27(3), p. 201214.

Mauborgne, R.- Kim, W. C. (2005): Blue Ocean StrategyHow to Create Uncontested Market Space and Make Competition Irrelevant. Boston: Harvard Business Review Press, 256 p. 
McGahan, A. M. - Porter, M. E. (1997): How much does industry matter, really? Strategic Management Journal, 18., p. $15-30$.

McGrath, R. G. (2013a): Transient advantage. Harvard Business Review, 91(6), p. 62-70.

McGrath, R. G. (2013b): The end of competitive advantage: How to keep your strategy moving as fast as your business. Boston: Harvard Business Review Press, 240 p.

Meyer, J. W. - Rowan, B. (1977): Institutionalized organizations: Formal structure as myth and ceremony. American Journal of Sociology, 83(2), p. 340-363.

Miller, D. (1986): Configurations of Strategy and Structure: Towards a Synthesis, Strategic Management Journal, 7(3), p. 233-249.

Miller, D. - Whitney, J. O. (1999): Beyond Strategy: Configuration as a Pillar of Competitive Advantage. Business Horizons, 42(3), p. 5-17.

Misangyi, V. F. et al. (2006): A New Perspective on a Fundamental Debate: A Multilevel Approach to Industry, Corporate and Business Unit Effects. Strategic Management Journal, 27(6), p. 571-590.

Montgomery, C. A. - Wernerfelt, B. (1988): Diversification, Ricardian Rents, and Tobin's q. The RAND Journal of Economics, 19(4), p. 623-632.

Nason, R. S. - Wiklund, J. (2018): An Assessment of Resource-Based Theorizing on Firm Growth and Suggestions for the Future. Journal of Management, 44(1), p. 32-60.

Osterwalder, A. - Pigneur, Y. (2010): Business model generation: a handbook for visionaries, game changers, and challengers. New York: John Wiley \& Sons, 288 p.

Penrose, E. T. (1959): The Theory of the Growth of the Firm. New York: John Wiley \& Sons, VIII+272 p.

Peteraf, M. A. (1993): The cornerstones of competitive advantage: A resource-based view. Strategic Management Journal, 14(3), p. 179-191.

Pfeffer, J. - Salancik, G. R. (1978): The external control of organizations: A resource dependence approach. New York: Harper and Row, XII+300 p.

Pfeffer, J. - Sutton, R. I. (2000): The knowing-doing gap: How Smart Companies Turn Knowledge in to Action. Boston: Harvard Business School Press, 114 p.

Porter, M. E. (1991): Towards a dynamic theory of strategy. Strategic Management Journal, 12(S2), p. 95-117.

Porter, M. E. (2006): Versenystratégia. 2. kiad. Budapest, Akadémiai Kiadó, 356 p. [Angolul: Porter, M. E. (1980): Competitive Strategy. Techniques for Analyzing Industries and Competitors. New York, Free Press, 396 p.]

Porter, M. E. (2008): The five competitive forces that shape strategy. Harvard Business Review, 86(1), p. 78-94.

Powell, T. C. (2003): Varieties of competitive parity. Strategic Management Journal, 24(1), p. 61-86.

Powell, T. C. (2004): Strategy, execution and idle rationality. Journal of Management Research, 4(2), p. 77-98.

Powell, T. C. - Lloyd, C. J. (2005): Toward a general theory of competitive dominance: comments and extensions on Powell (2003). Strategic Management Journal, 26(4), p. 385-394.

Powell, T. C. - Arregle, J. L. (2007): Firm performance and the axis of errors. Journal of Management Research, 7(2), p. 59-77.
Powell, T. C. - Lovallo, D. - Fox, C. R. (2011): Behavioral strategy. Strategic Management Journal, 32(13), p. 1369-1386.

Prahalad, C. K. - Hamel, G. (1990): The Core Competence of the Corporation. Harvard Business Review, 68(3), p. 79-91.

Priem, R. L. - Butler, J. E. (2001): Is the Resource-Based „View” a Useful Perspective for Strategic Management Research? Academy of Management Review, 26(1), p. 22-40.

Rideg A. (2014): Versenyképesség és stratégia a Toyota termelési rendszerében. In: Szabó I. (szerk.): II. Interdiszciplinárius Doktorandusz Konferencia, Konferenciakötet. Pécs: Doktoranduszok Országos Szövetsége Közgazdaságtudományi Osztály, p. 585-592.

Roquebert, J. A. - Phillips, R. L. -Westfall, P. A. (1996): Markets vs. Management: What „Drives” Profitability? Strategic Management Journal, 17(8), p. 653-664.

Rosenzweig, E. D. - Roth, A. V. - Dean, J. W. (2003): The influence of an integration strategy on competitive capabilities and business performance: An exploratory study of consumer products manufacturer. Journal of Operation Management, 21(4), p. 437-456.

Rugman, A. M. - Verbeke, A. (2002): Edith Penrose's contribution to the resource-based view of strategic management. Strategic Management Journal, 23(8), p. 769-780.

Rumelt, R. P. (1984): Towards a strategic theory of the firm. In: Lamb, R. B. (ed.): Competitive Strategic Management. Englewood Cliffs; New York: Prentice Hall, p. 556-570.

Rumelt, R. P. (1991): How much does industry matter? Strategic Management Journal, 12(3), p. 167-185.

Schmalensee, R. (1985): Do markets differ much? American Economic Review 75(3), p. 341-351.

Şimşit, Z. T. - Günay, N. S. - Vayvay, Ö. (2014): Theory of Constraints: A Literature Review. Procedia-Social and Behavioral Sciences, 150., p. 930-936.

Stamatis, D. H. (2004): Six Sigma Fundamentals: A Complete Guide to the System, Methods, and Tools. New York: Productivity Press, 345 p.

Suchman, M. C. (1995): Managing legitimacy: Strategic and institutional approaches. Academy of Management Review, 20(3), p. 571-610.

Teece, D. J. (1984): Economic Analysis and Strategic Management. California Management Review, 20(3), p. 87-110.

Teece, D. J. - Pisano, G. - Shuen, A. (1997): Dynamic Capabilities and Strategic Management. Strategic Management Journal, 18(7), p. 509-533.

Teece, D. J. (2010): Business models, business strategy and innovation. Long Range Planning, 43(2), p. 172-194.

Watson, K. J. - Blackstone, J. H. - Gardiner, S. C. (2007): The evolution of a management philosophy: The theory of constraints. Journal of Operations Management, 25(2), p. 387-402.

Wernerfelt, B. (1984): A Resource-Based View of the Firm. Strategic Management Journal, 5(2), p. 171-180.

Wernerfelt, B. (1995): The Resource-Based View of the Firm: Ten Years After. Strategic Management Journal, 16(3), p. 171- 174.

West III, P. - DeCastro, J. (2001): The Achilles heel of firm strategy: resource weaknesses and distinctive inadequacies. Journal of Management Studies, 38(3), p. 417-442.

Zott, C. - Amit, R. (2010): Business model design: an activity system perspective. Long Range Planning, 43(2), p. 216-226. 